\title{
Extended evaluation of the safety and efficacy of GAD treatment of children and adolescents with recent-onset type 1 diabetes: a randomised controlled trial
}

\author{
J. Ludvigsson • M. Hjorth • M. Chéramy • S. Axelsson • M. Pihl • G. Forsander • \\ N.-Ö. Nilsson • B.-O. Samuelsson • T. Wood • J. Åman • E. Örtqvist • R. Casas
}

Received: 26 March 2010 /Accepted: 29 October 2010/Published online: 30 November 2010

(C) Springer-Verlag 2010

\begin{abstract}
Aims/hypothesis The aim of this study was to investigate the safety and efficacy of alum formulated glutamic acid decarboxylase $\mathrm{GAD}_{65}$ (GAD-alum) treatment of children and adolescents with type 1 diabetes after 4 years of follow-up. Methods Seventy children and adolescents aged 10-18 years with recent onset type 1 diabetes participated in a phase II, double-blind, randomised placebo-controlled clinical trial. Patients identified as possible participants attended one of
\end{abstract}

J. Ludvigsson $(\bowtie) \cdot$ M. Hjorth $\cdot$ M. Chéramy $\cdot$ S. Axelsson $\cdot$

M. Pihl · R. Casas

Division of Pediatrics,

Department of Clinical and Experimental Medicine,

Faculty of Health Sciences, Linköping University,

SE-58185, Linköping, Sweden

e-mail: johnny.ludvigsson@lio.se

\section{G. Forsander}

The Queen Silvia Children's Hospital,

Gothenburg, Sweden

N.-Ö. Nilsson

Halmstad County Hospital,

Halmstad, Sweden

B.-O. Samuelsson

Department of Pediatrics, Borås Hospital,

Borås, Sweden

T. Wood

Diamyd Therapeutics,

Stockholm, Sweden

J. Åman

Örebro University Hospital,

Örebro, Sweden

E. Örtqvist

Karolinska University Hospital,

Stockholm, Sweden eight clinics in Sweden to receive information about the study and for an eligibility check, including a medical history. Participants were randomised to one of the two treatment groups and received either a subcutaneous injection of $20 \mu \mathrm{g}$ of GAD-alum or placebo at baseline and 1 month later. The study was blinded to participants and investigators until month 30 . The study was unblinded at 15 months to the sponsor and statistician in order to evaluate the data. At follow-up after 30 months there was a significant preservation of residual insulin secretion, as measured by C-peptide, in the group receiving GAD-alum compared with placebo. This was particularly evident in patients with $<6$ months disease duration at baseline. There were no treatment-related serious adverse events. We have now followed these patients for 4 years. Overall, 59 patients, 29 who had been treated with GAD-alum and 30 who had received placebo, gave their informed consent.

Results One patient in each treatment group experienced an episode of keto-acidosis between months 30 and 48. There were no treatment-related adverse events. The primary efficacy endpoint was the change in fasting C-peptide concentration from baseline to 15 months after the prime injection for all participants per protocol set. In the GADalum group fasting C-peptide was $0.332 \pm 0.032 \mathrm{nmol} / 1$ at day 1 and $0.215 \pm 0.031 \mathrm{nmol} / 1$ at month 15 . The corresponding figures for the placebo group were $0.354 \pm$ 0.039 and $0.184 \pm 0.033 \mathrm{nmol} / \mathrm{l}$, respectively. The decline in fasting C-peptide levels between day 1 and month 1 , was smaller in the GAD-alum group than the placebo group. The difference between the treatment groups was not statistically significant. In those patients who were treated within 6 months of diabetes diagnosis, fasting C-peptide had decreased significantly less in the GADalum group than in the placebo-treated group after 4 years. 
Conclusion/interpretation Four years after treatment with GAD-alum, children and adolescents with recent-onset type 1 diabetes continue to show no adverse events and possibly to show clinically relevant preservation of C-peptide.

\section{Trial registration ClinicalTrials.gov NCT00435981}

Funding The study was funded by The Swedish Research Council K2008-55X-20652-01-3, Barndiabetesfonden (The Swedish Child Diabetes Foundation), the Research Council of Southeast Sweden, and an unrestricted grant from Diamyd Medical AB.

Keywords C-peptide - Children - GAD-alum treatment . Immune modulation - Type 1 diabetes

\begin{tabular}{|c|c|}
\hline \multicolumn{2}{|c|}{ Abbreviations } \\
\hline ANCOVA & Analysis of covariance \\
\hline $\mathrm{GAD}_{65}$ & Glutamic acid decarboxylase 65 \\
\hline GADA & $\mathrm{GAD}_{65}$ auto-antibodies \\
\hline GAD-alum & $\begin{array}{l}\text { Alum formulated glutamic acid decarboxyl- } \\
\text { ase } 65\end{array}$ \\
\hline LADA & Latent autoimmune diabetes in adults \\
\hline MMTT & Mixed meal tolerance test \\
\hline $\operatorname{rhGAD}_{65}$ & Recombinant human $\mathrm{GAD}_{65}$ \\
\hline
\end{tabular}

\section{Introduction}

In spite of intensive treatment, type 1 diabetes causes substantial morbidity and mortality $[1,2]$. Residual insulin secretion facilitates metabolic control and decreases the risk of keto-acidosis [3], and even modest beta cell function, with stimulated $\mathrm{C}$-peptide above $0.2 \mathrm{nmol} / \mathrm{l}$, may reduce long-term complications [4]. Type 1 diabetes is an autoimmune disease [5]; however, most attempts to use immune intervention to preserve residual beta cell function have achieved limited benefits or have been associated with adverse effects [6-19]. Treatment with anti-CD3 monoclonal antibodies appears to be the most promising treatment to date, but several patients treated in this way, as well as with anti-CD20 monoclonal antibodies, have experienced treatment-related adverse events [20, 21].

Auto-antigens may be used to induce immunological tolerance [22]. Insulin and glutamic acid decarboxylase 65 $\left(\mathrm{GAD}_{65}\right)$ are major auto-antigens in type 1 diabetes [23, 24] and have been tested in immunomodulation experiments [25]. Data from studies of the spontaneously diabetic NOD mouse have indicated that $\mathrm{GAD}_{65}$ prevents type 1 diabetes $[26,27]$. A dose-finding study in patients with latent autoimmune diabetes in adults (LADA) indicated that a prime and boost injection of $20 \mu \mathrm{g}$ GAD-alum (recombinant human $\mathrm{GAD}_{65}$ in a standard vaccine formulation with alum) might preserve residual insulin secretion [28]. This treatment was easy to perform and well tolerated by the patients, and at a follow-up after 5 years there were no treatment-related adverse events and potential efficacy was reported in one of the subgroups [29].

We administered GAD-alum or placebo to 70 young patients with recent-onset type 1 diabetes in order to test whether it would reduce or halt the loss of residual insulin secretion [30]. The results of the 15 month study period followed by 15 months of further observation showed significant preservation of residual insulin secretion for at least 30 months. The efficacy was mainly restricted to patients with $<6$ months duration of diabetes when receiving their first GAD-alum injection. The treatment was very well tolerated by the patients and no treatmentrelated adverse events were seen. We now report the results of an extended follow-up after 4 years to evaluate the longterm clinical effect and safety.

\section{Methods}

In total 118 patients were screened, and 70 of these were found to be eligible for inclusion in the treatment phase of the study (Fig. 1). The first patient was enrolled in February 2005. The 70 patients were randomised to a double-blind treatment with either $20 \mu \mathrm{g}$ of recombinant human $\mathrm{GAD}_{65}$ $\left(\right.$ rhGAD ${ }_{65}$ ) formulated in alum (Diamyd; Diamyd Medical, Stockholm, Sweden; 35 patients) or placebo (the same formulation without $\mathrm{rhGAD}_{65} ; 35$ patients) [30]. Thus each patient received a subcutaneous primary injection of either GAD-alum or placebo on day 1 followed by a boost 1 month later. All but one patient received two doses of either GAD-alum or placebo (Fig. 1). One patient (a girl in the placebo group) was withdrawn from the study after 1 week; she received only one injection and was lost to follow-up. A total of 69 patients, 35 in the GAD-alum group and 34 in the placebo group, completed the original 30 month study period. Participants had been diagnosed with type 1 diabetes within the previous 18 months before screening. The inclusion criteria were $\mathrm{GAD}_{65}$ autoantibodies (GADA) and fasting C-peptide levels above $0.1 \mathrm{nmol} / 1$. All patients were treated with multiple daily injections of insulin with a target $\mathrm{HbA}_{1 \mathrm{c}}$ level of less than $6.5 \%$ (corresponding to $<7.5 \%$ DCCT value). At baseline two patients in the placebo group but no patients in the GAD-alum treated group were using an insulin pump. Blinding of participants and investigators to GAD-alum or placebo was removed at month 30 .

After 4 years, all the patients and, for those children $<18$ years old, their parents, were contacted and asked whether they were willing to participate in a follow-up study. All 69 remaining patients could be reached but only 
Fig. 1 Disposition of patients. Enrolment, randomisation and allocation of patients to treatment groups during the main study period and

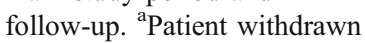
from study because of mononucleosis with icterus

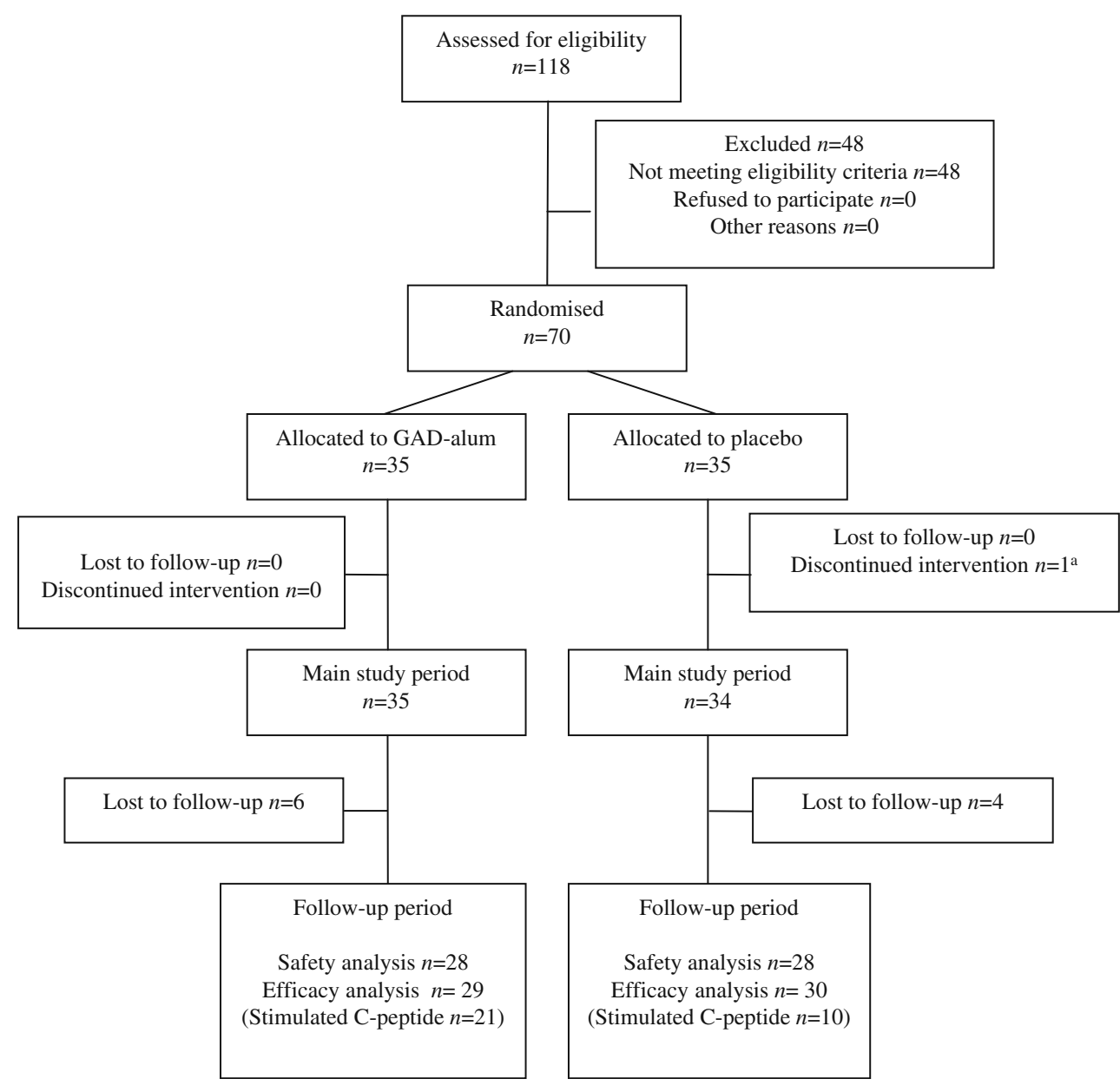

59 patients agreed to participate, of whom 29 had been treated with GAD-alum and 30 had received placebo. Several of the patients had left their original paediatric clinic and moved to alternative clinics. It took some time to obtain ethics approval for those new clinics, to recruit and inform physicians and nurses willing to participate in the follow-up, and then finally to organise visits. Therefore, the follow-up was not performed until 49-52 months after the first injection of study drug. Baseline demographic and clinical characteristics of treatment groups are shown in Table 1 . Safety data were reported for 56 patients, 28 in each treatment arm. This study was approved by the Research Ethics Committee at the Faculty of Health Sciences, Linköping University, Sweden and the regulatory authorities in Sweden. Written informed consent was obtained from participating individuals in accordance with the Declaration of Helsinki.

A fasting blood sample was received from all 59 patients. We were concerned that excessive demands might cause patients to refuse to participate in the follow-up. We therefore decided to perform a mixed meal tolerance test (MMTT) in accordance with the European study on estimation of beta cell function [31] in only those 31 patients (21 in the GAD-alum group and 10 in the placebo-group) who at the 30 month follow-up had a maximal C-peptide response $>0.20 \mathrm{nmol} / \mathrm{l}$. This test includes ingestion of $6 \mathrm{ml}$ Sustacal (Sustacal; Mead Johnson, Evansville, IN, USA)/kg of body weight, with a maximum of $360 \mathrm{ml}$, to be ingested within $5 \mathrm{~min}$. The meal test was performed in the morning (between 07:00 and 10:00 hours) after an overnight fast, in which no food or drink (with the exception of water) and no smoking occurred after 22:00 the preceding day. The patients took no short-acting insulin for at least $6 \mathrm{~h}$ before the test. Patients on continuous subcutaneous insulin infusion continued their normal basal rate, but received no added boluses for at least $6 \mathrm{~h}$ prior to the test.

A general physical examination including vital signs (supine blood pressure, pulse rate, weight and height, BMI) and a neurological examination (patellar reflex, Achilles reflex, vibration sensitivity big toe, and muscle tonus) were conducted.

Blood samples for C-peptide analysis were collected before and at 30,60, 90 and $120 \mathrm{~min}$ after the beginning of the MMTT. Other evaluations included clinical examination, haematology, biochemistry, blood glucose and insulin requirement (units per kg body weight and per $24 \mathrm{~h}$ ).

C-peptide levels were measured as the study progressed in serum samples with a time-resolved fluoroimmunoassay 
Table 1 Baseline demographic and clinical characteristics of treatment groups

\begin{tabular}{|c|c|c|c|c|c|c|}
\hline \multirow[t]{2}{*}{ Characteristic } & \multicolumn{2}{|l|}{ All patients } & \multicolumn{2}{|c|}{ Included in follow-up } & \multicolumn{2}{|c|}{ Excluded from follow-up } \\
\hline & $\begin{array}{l}\text { GAD-alum } \\
(n=35)\end{array}$ & $\begin{array}{l}\text { Placebo } \\
(n=34)\end{array}$ & $\begin{array}{l}\text { GAD-alum } \\
(n=29)\end{array}$ & $\begin{array}{l}\text { Placebo } \\
(n=0)\end{array}$ & $\begin{array}{l}\text { GAD-alum } \\
(n=6)\end{array}$ & $\begin{array}{l}\text { Placebo } \\
(n=4)\end{array}$ \\
\hline Age (years) & $13.8 \pm 2.3$ & $12.8 \pm 1.9$ & $13.6 \pm 2.4$ & $12.8 \pm 1.9$ & $14.7 \pm 2.0$ & $12.7 \pm 2.0$ \\
\hline Duration of diabetes (months) & $9.9 \pm 5.3$ & $8.8 \pm 5.4$ & $9.4 \pm 5.4$ & $8.5 \pm 5.4$ & $12.2 \pm 4.5$ & $10.8 \pm 5.9$ \\
\hline BMI at screening $\left(\mathrm{kg} / \mathrm{m}^{2}\right)$ & $19.5 \pm 2.4$ & $20.5 \pm 3.2$ & $19.1 \pm 2.3$ & $20.3 \pm 3.0$ & $20.4 \pm 2.7$ & $21.4 \pm 4.6$ \\
\hline \multicolumn{7}{|l|}{ Sex distribution, $n(\%)$} \\
\hline Female & $23(66)$ & $18(53)$ & $19(65.5)$ & $15(50)$ & $4(66.6)$ & $3(75)$ \\
\hline Male & $12(34)$ & $16(47)$ & $10(34.5)$ & $15(50)$ & $2(33.3)$ & $1(25)$ \\
\hline Fasting C-peptide (nmol/1) & $0.3 \pm 0.2$ & $0.4 \pm 0.2$ & $0.3 \pm 0.2$ & $0.4 \pm 0.2$ & $0.4 \pm 0.2$ & $0.4 \pm 0.3$ \\
\hline Stimulated C-peptide AUC $(\mathrm{nmol} / 1 \times 2 \mathrm{~h})$ & $1.2 \pm 0.6$ & $1.4 \pm 0.9$ & $1.3 \pm 0.6$ & $1.4 \pm 0.9$ & $1.1 \pm 0.5$ & $1.3 \pm 0.9$ \\
\hline $\mathrm{HbA}_{1 \mathrm{c}}(\%)$ & $6.3 \pm 1.3$ & $6.2 \pm 1.0$ & $6.2 \pm 1.3$ & $6.2 \pm 0.9$ & $6.8 \pm 1.1$ & $6.9 \pm 1.0$ \\
\hline Insulin dose/kg bodyweight (U/kg) & $0.7 \pm 0.3$ & $0.7 \pm 0.3$ & $0.7 \pm 0.3$ & $0.6 \pm 0.3$ & $0.7 \pm 0.2$ & $0.8 \pm 0.4$ \\
\hline Plasma glucose prior to MMTT (mmol/1) & $9.4 \pm 4.0$ & $8.8 \pm 3.3$ & $9.5 \pm 4.1$ & $8.7 \pm 3.4$ & $8.8 \pm 3.5$ & $8.8 \pm 1.3$ \\
\hline Fasting C-peptide/plasma glucose $\times 10^{-12}$ & $40 \pm 23$ & $45 \pm 29$ & $40 \pm 23$ & $45 \pm 29$ & $41 \pm 22$ & $42 \pm 37$ \\
\hline Median GADA titre (U/ml) & 601 & 861 & 539 & 786 & 1028 & 1637 \\
\hline
\end{tabular}

Values are mean \pm SD unless stated otherwise

(AutoDELFIA C-peptide kit; Wallac, Turku, Finland). Results were validated with inclusion of a C-peptide control module containing a high, a medium and a low-level control in each assay (Immulite; DPC, Llanberis, UK). The 1224 MultiCalc programme (Wallac) was used for automatic measurement and result calculation and measurements were expressed in nmol/l.

$\mathrm{HbA}_{1 \mathrm{c}}$ was analysed by an immunological method, calibrated against the Swedish national standard Mono-S and continuously controlled against the External Quality Assurance in Laboratory Medicine in Sweden (EQALIS) reference method.

Statistical analyses Data management and statistical analyses were performed by the contract research organisation Trial Form Support AB, Lund, Sweden. An analysis of covariance (ANCOVA) model was used for formal analysis where the change from baseline was taken as the response variable, treatment as the explanatory variable and the baseline value as a covariate. Subgroup analysis of patients with $<6$ months diabetes duration at baseline was done as specified in the analysis plan for the original study [30]. Results are presented as means \pm SEM. $p$ values $<0.05$ were regarded as statistically significant.

\section{Results}

Baseline demographic and clinical characteristics of all the participants in the phase II trial are illustrated in Table 1. In addition, the same information for patients who later participated or were excluded from the 4 year follow-up is shown.

As the study was unblinded at the 30 month follow-up, we searched to see if there was a difference in the 30 month C-peptide levels between the patients who decided to

Table 2 C-peptide levels (nmol/l) at 30 months for patients participating at the 4 year control and for those who dropped out

\begin{tabular}{|c|c|c|c|c|}
\hline \multirow[t]{2}{*}{ Patients } & \multicolumn{2}{|l|}{ GAD-alum } & \multicolumn{2}{|l|}{ Placebo } \\
\hline & Number of patients & C-peptide (nmol/l) & Number of patients & C-peptide $(\mathrm{nmol} / \mathrm{l})$ \\
\hline \multicolumn{5}{|l|}{ All patients } \\
\hline Continued in the trial & 29 & $0.13 \pm 0.02$ & 30 & $0.09 \pm 0.02$ \\
\hline Dropped out & 6 & $0.11 \pm 0.03$ & 4 & $0.10 \pm 0.04$ \\
\hline \multicolumn{5}{|c|}{ Patients $<6$ months diabetes duration } \\
\hline Continued in the trial & 10 & $0.19 \pm 0.03$ & 13 & $0.09 \pm 0.03$ \\
\hline Dropped out & 1 & 0.06 & 1 & 0.03 \\
\hline
\end{tabular}




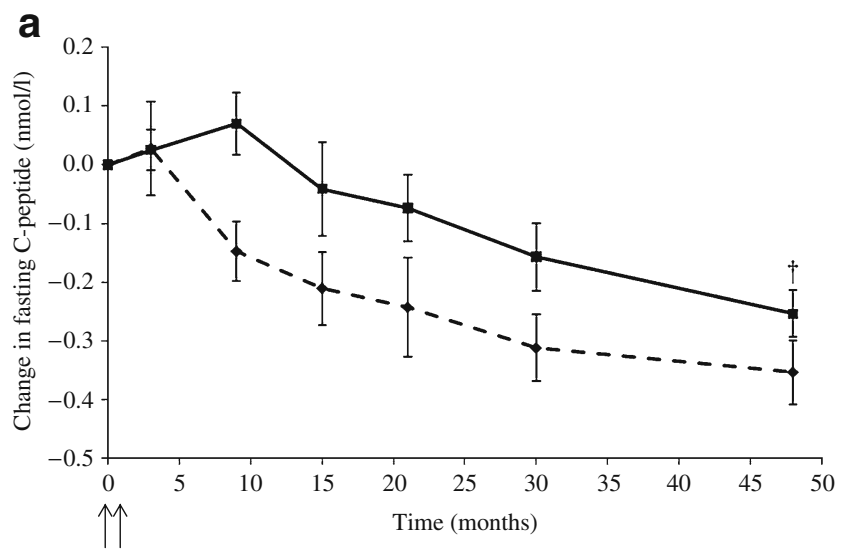

Injections

b

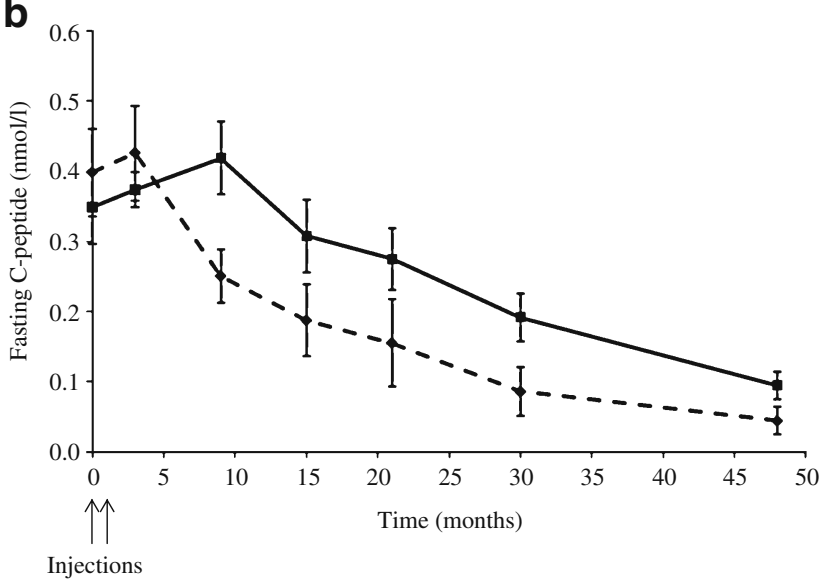

Fig. 2 Mean change in fasting C-peptide and total C-peptide. a Mean change from baseline to 48 months (4 years) in fasting C-peptide and b total C-peptide (nmol/1) at each time point are shown for follow-up patients treated within 6 months of diagnosis of type 1 diabetes (10 patients in the GAD-alum group [solid line with black squares] and 13 patients in the placebo group [dashed line with black diamonds]). Bars indicate standard error. $\uparrow p=0.02$

participate in the 4 year follow-up, and those who dropped out, both for the entire cohort and for the group who had $<6$ months duration of diabetes at baseline. When all patients participating in the trial were compared, no difference between patients who continued in the study and those who dropped out was observed, either for the GAD-alum or the placebo group. Among the patients with $<6$ months duration of diabetes, only one patient from the GAD-alum group and one from the placebo group dropped out from the 48 month follow-up (Table 2).

Reported adverse events There were four adverse events reported in four patients treated with GAD-alum and six adverse events reported in five patients in the placebo group. One diabetic keto-acidosis in each treatment group led to hospitalisation; this is to be regarded as a serious adverse event. None of the events were considered to be treatment-related. In addition to these adverse events there were two self-reported severe hypoglycaemia episodes in two patients in the GAD-alum group and five severe hypoglycaemia episodes in four patients in the placebo group.

Physical examination With the exception of one patient with restricted patellar reflex and one patient with low vibration sense in the GAD-alum group, nothing abnormal was found in the neurological examination. The physical examination showed nothing abnormal.

C-peptide At 4 years there was a continued significant preservation of fasting C-peptide after treatment with GADalum compared with placebo in patients who had $<6$ months diabetes duration at baseline $(p=0.02$; Fig. 2). The previously observed effect of GAD-alum treatment on the change in fasting C-peptide level for all patients [30] was still apparent at the 4 year follow-up, although it was not statistically significant (Fig. 3). There was no difference in

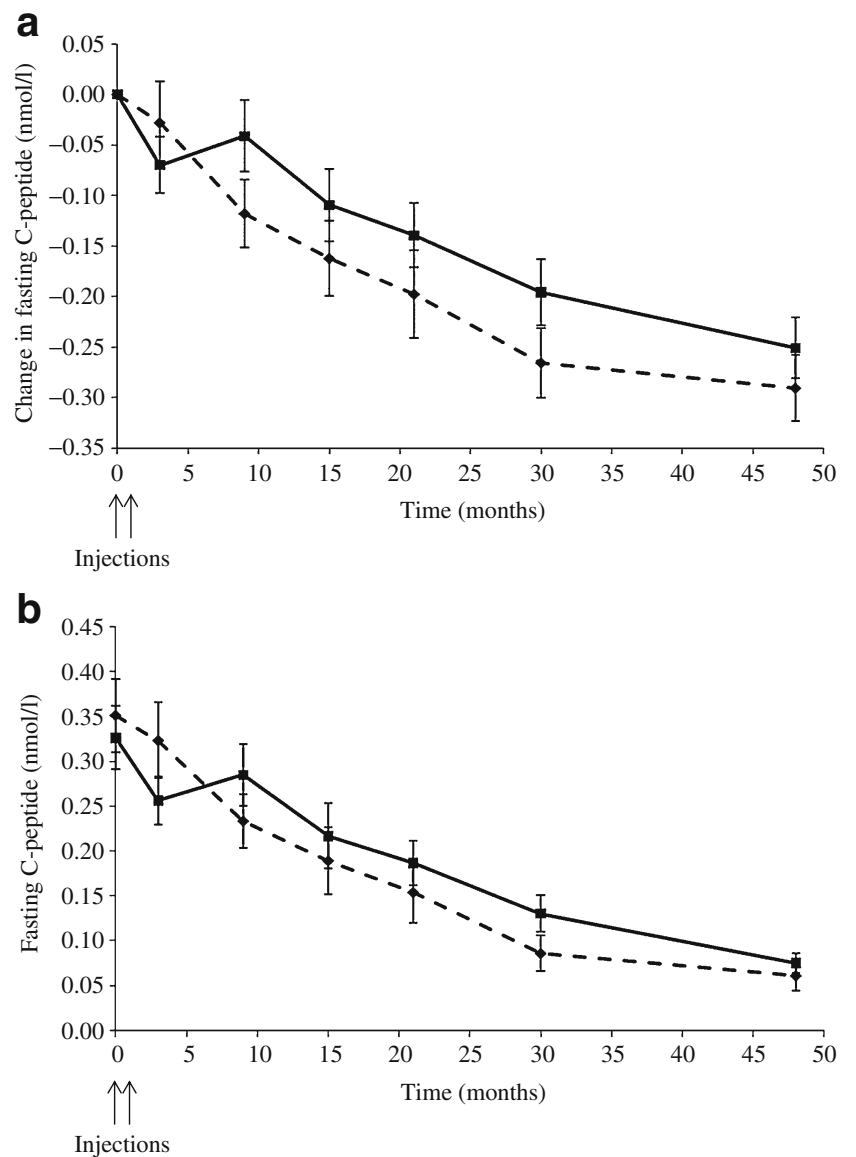

Fig. 3 Mean change in fasting c-peptide and total c-peptide. a Mean change from baseline to 48 months in fasting C-peptide and $\mathbf{b}$ total C-peptide at each time $(\mathrm{nmol} / \mathrm{l})$ are shown for all follow-up patients (29 patients in the GAD-alum group [solid line with black squares] and 30 patients in the placebo group [dashed line with black diamonds]). Bars indicate standard error 
fasting C-peptide between GAD-alum treated and placebo treated patients who had a diabetes duration $\geq 6$ months at baseline.

For the follow-up study, the MMTT was performed only in the selected group of patients who had a maximal C-peptide response of $>0.20 \mathrm{nmol} / 1$ at the 30 month followup, that is in $21 \mathrm{GAD}$-alum treated patients and 10 patients in the placebo group. After $2 \mathrm{~h} \mathrm{MMTT}$, the change of stimulated C-peptide secretion from baseline up to 4 years seemed to decrease less in the individuals who received GAD-alum (mean change $-0.990 \pm 0.085 \mathrm{nmol} / \mathrm{l}$ ) than in the placebo group (mean change $-1.202 \pm 0.0148 \mathrm{nmol} / \mathrm{l}$ ). The difference in change between the two groups remained constant at $0.212 \mathrm{nmol} / \mathrm{l}$, but was no longer statistically significant, as previously reported for the 30 month followup [30].

Exploratory subgroup analysis was done as specified in the analysis plan for the original study [30]. Duration of diabetes at baseline was found to influence the degree of $\mathrm{C}$ peptide preservation but no other factor at baseline (age, BMI, sex, fasting C-peptide, stimulated C-peptide at treatment, $\mathrm{HbA}_{1 \mathrm{c}}$, insulin dose per $\mathrm{kg}$ body weight, glucose before MMTT, or fasting C-peptide/glucose).

\section{Discussion}

The initial phase II trial, aimed at studying the safety and efficacy of GAD-alum treatment, was designed with a study period of 30 months. Several of the adolescents or young adults were not willing to participate in an extended followup, which might disrupt their other activities. This explains why we could not follow up more than 59/69 patients $(85.5 \%)$. The small sample limits our chances of showing statistically significant differences, but as shown in Table 1 there is no difference in baseline data prior to treatment between those patients who participated in the follow-up and those who did not, and therefore selection bias should not explain our results. The analysis of the 30 month $\mathrm{C}$ peptide data for the patients remaining in the 4 year study and those who dropped out, both for all the patients and the group with $<6$ months diabetes duration, shows that the unblinding at the 30 month follow-up did not introduce a bias into the subsequent population participating at the 4 year control. We also believe that the results are complete enough to show that, even 4 years after the GAD-alum treatment, there were no treatment-related adverse events, neither according to history, nor according to self-reported numbers of keto-acidosis or severe hypoglycaemia, nor according to physical examination.

With respect to the efficacy data, we should be cautious about drawing conclusions. The study is no longer double blinded, which might influence the treatment and clinical efficacy. Four years after treatment, fasting C-peptide, the primary endpoint in the original study, remained significantly better preserved in patients with $<6$ months diabetes duration at baseline, a subgroup specified in the original analysis plan. No other factor than duration of diabetes at baseline was found to influence the response to GAD treatment.

As the MMTT was difficult to motivate in patients who already had very low residual insulin secretion at the 30 month follow-up, we performed such tests only in a selected group of patients with a maximal response of $\mathrm{C}$ peptide $>0.20 \mathrm{nmol} / 1$ at 30 months. This clearly limits our chances of seeing an effect of treatment and consequently we can only conclude that the decline in C-peptide AUC was no faster in the GAD-alum treated group than in the placebo treated group.

In conclusion, treatment of children and adolescents with recent-onset type 1 diabetes with GAD-alum has led to no adverse events, still 4 years after administration. Fasting $\mathrm{C}$ peptide remains significantly better preserved relative to placebo in those patients with $<6$ months diabetes duration at baseline, which suggests a reasonably long-standing efficacy.

Acknowledgements The GAD-alum studies have been possible thanks to several collaborators at the Division of Pediatrics and Diabetes Research Centre, Linköping University, and we want to thank L. Berglert, I. Johansson and G. Smolinska for laboratory assistance, the research nurses E. Isacson, A-M. Sandström, and all physicians (K. E. Åkesson, J. Fowelin, A. Frid, H. Larsson, A. Pundziute-Lyckå, O. Strandberg and K. Wahlin) and nurses involved at different Swedish clinics.

Duality of interest Diamyd Medical $\mathrm{AB}$ has been/is the sponsor of the phase II/III trials and has also given financial support for investigator-initiated mechanistic studies. Diamyd Medical $\mathrm{AB}$ as sponsor was involved in the planning, monitoring and quality assurance of the phase II study according to ICH (International Conference on Harmonisation of Technical Requirements for Registration of Pharmaceuticals for Human Use) good clinical practice.

\section{References}

1. The Diabetes Control and Complications Trial Research Group (1993) The effect of intensive treatment of diabetes on the development and progression of long-term complications in insulin-dependent diabetes mellitus. N Engl J Med 329:977986

2. Bojestig M, Arnqvist HJ, Hermansson G, Karlberg BE, Ludvigsson J (1994) Declining incidence of nephropathy in insulindependent diabetes mellitus. N Engl J Med 330:15-18

3. Madsbad S, Alberti KG, Binder C et al (1979) Role of residual insulin secretion in protecting against ketoacidosis in insulindependent diabetes. BMJ 2:1257-1259

4. Steffes MW, Sibley S, Jackson M, Thomas W (2003) Beta-cell function and the development of diabetes-related complications in the Diabetes Control and Complications Trial. Diab Care 26:832-836 
5. Atkinson MA, Eisenbarth GS (2001) Type 1 diabetes: new perspectives on disease pathogenesis and treatment. Lancet 358:221-229

6. Ludvigsson J, Heding L, Lieden G, Marner B, Lernmark A (1983) Plasmapheresis in the initial treatment of insulin-dependent diabetes mellitus in children. BMJ (Clin Res Ed) 286:176-178

7. Dupre J, Stiller CR, Gent M et al (1988) Clinical trials of Cyclosporin in IDDM. Diab Care 11(suppl 1):37-44

8. Eisenbarth GS, Srikanta S, Jackson R et al (1985) Anti-thymocyte globulin and prednisone immunotherapy of recent onset type 1 diabetes mellitus. Diab Res 2:271-276

9. Chase HP, Butler-Simon N, Garg S, McDuffie M, Hoops SL, O'Brien D (1990) A trial of nicotinamide in newly diagnosed patients with type 1 (insulin-dependent) diabetes mellitus. Diabetologia 33:444-446

10. Pozzilli P, Visalli N, Signore A et al (1995) Double blind trial of nicotinamide in recent-onset IDDM (the IMDIAB III study). Diabetologia 38:848-852

11. Coutant R, Landais P, Rosilio M et al (1998) Low dose linomide in type I juvenile diabetes of recent onset: a randomised placebocontrolled double blind trial. Diabetologia 41:1040-1046

12. Ludvigsson J, Samuelsson U, Johansson C, Stenhammar L (2001) Treatment with antioxidants at onset of type 1 diabetes in children: a randomized, double-blind placebo-controlled study. Diab Metab Res Rev 17:131-136

13. Ludvigsson J, Samuelsson U, Ernerudh J, Johansson C, Stenhammar L, Berlin G (2001) Photopheresis at onset of type 1 diabetes: a randomized, double blind, placebo controlled trial. Arch Dis Child 85:149-154

14. Raz I, Elias D, Avron A, Tamir M, Metzger M, Cohen IR (2001) Beta-cell function in new-onset type 1 diabetes and immunomodulation with a heat-shock protein peptide (DiaPep277): a randomised, double-blind, phase II trial. Lancet 358:1749-1753

15. Lazar L, Ofan R, Weintrob N et al (2007) Heat-shock protein peptide DiaPep277 treatment in children with newly diagnosed type 1 diabetes: a randomised, double-blind phase II study. Diab Metab Res Rev 23:286-291

16. Larsen CM, Faulenbach M, Vaag A et al (2007) Interleukin-1receptor antagonist in type 2 diabetes mellitus. N Engl J Med 356:1517-1526

17. Mandrup-Poulsen T, Pickersgill L, Donath M (2010) Blockade of interleukin 1 in type 1 diabetes mellitus. Nat Rev Endocrinol 6:158-166

18. Rother KI, Brown RJ, Morales MM et al (2009) Effect of ingested interferon-alpha on beta-cell function in children with new-onset type 1 diabetes. Diab Care 32:1250-1255
19. Pescovitz MD, Greenbaum CJ, Krause-Steinrauf H et al (2009) Type 1 Diabetes TrialNet Anti-CD20 Study Group Rituximab, Blymphocyte depletion, and preservation of beta-cell function. $\mathrm{N}$ Engl J Med 361:2143-2152

20. Herold KC, Gitelman SE, Masharani U et al (2005) A single course of anti-CD3 monoclonal antibody hOKT3gamma1 (AlaAla) results in improvement in C-peptide responses and clinical parameters for at least 2 years after onset of type 1 diabetes. Diabetes 54:1763-1769

21. Keymeulen B, Vandemeulebroucke E, Ziegler AG et al (2005) Insulin needs after CD3-antibody therapy in new-onset type 1 diabetes. N Engl J Med 352:2598-2608

22. Ludvigsson J (2009) Adequate doses of autoantigen administered using the appropriate route may create tolerance and stop autoimmunity. Diabetologia 52(1):175-176

23. Jasinski JM, Eisenbarth GS (2005) Insulin as a primary autoantigen for type 1A diabetes. Clin Dev Immunol 12:181-186

24. Baekkeskov S, Nielsen JH, Marner H, Bilde T, Ludvigsson J, Lernmark A (1982) Autoantibodies in newly diagnosed diabetic children immunoprecipitate human pancreatic islet cell proteins. Nature 298:167-169

25. Lernmark A, Agardh CD (2005) Immunomodulation with human recombinant autoantigens. Trends Immunol 26:608-612

26. Tian J, Clare-Salzler M, Herschenfeld A et al (1996) Modulating autoimmune responses to GAD inhibits disease progression and prolongs islet graft survival in diabetes-prone mice. Nat Med 2:1348-1353

27. Tisch R, Liblau RS, Yang XD, Liblau P, McDevitt HO (1998) Induction of GAD65-specific regulatory T cells inhibits ongoing autoimmune diabetes in non-obese diabetic mice. Diabetes 47:894-899

28. Agardh CD, Cilio CM, Lethagen A et al (2005) Clinical evidence for the safety of GAD65 immunomodulation in adult-onset autoimmune diabetes. J Diabetes Complications 19:238-246

29. Agardh C-D, Lynch K, Palmér M, Link K, Lenmark Å (2009) GAD65 vaccination: 5-years follow-up in a randomised doseescalating study in adult-onset autoimmune diabetes. Diabetologia 52:1363-1368

30. Ludvigsson J, Faresjö M, Hjorth M et al (2008) GAD treatment and insulin secretion in recent onset type 1 diabetes. N Engl J Med 359:1909-1920

31. Greenbaum CJ, Mandrup-Poulsen T, McGee PF, Type 1 Diabetes Trial Net Research Group European C-Peptide Trial Study Group et al (2008) Mixed meal tolerance test vs the glucagon stimulation test for the assessment of beta-cell function in therapeutic trials in type 1 diabetes. Diab Care 31:1966-1971 